\title{
Antioxidant potential of methanolic extracts and powders of some Cameroonian spices during accelerated storage of soybean oil
}

\author{
Hilaire Macaire Womeni ${ }^{1 *}$, Fabrice Tonfack Djikeng ${ }^{1}$, Bernard Tiencheu ${ }^{1}$, Michel Linder ${ }^{2}$ \\ ${ }^{1}$ Department of Biochemistry, Faculty of Science, University of Dschang, Dschang, Cameroon \\ ${ }^{2}$ Biomolecular Engineering Laboratory (LIBio), Université de Lorraine, ENSAIA, Vandoeuvre-les-Nancy, France \\ Email: ${ }^{*}$ womeni@yahoo.fr
}

Received 4 March 2013; revised 28 April 2013; accepted 16 May 2013

Copyright (C) 2013 Hilaire Macaire Womeni et al. This is an open access article distributed under the Creative Commons Attribution License, which permits unrestricted use, distribution, and reproduction in any medium, provided the original work is properly cited.

\begin{abstract}
The efficacy of methanolic extracts and powders of 12 spices (Pimpinella anisum, Scorodophleuszenkeii, $\mathrm{Xy}$ lopiaparviflora, Eugenia caryophyllus, Fagara leprieurii, Fagara macrophylla, Monodora myristica, Olax subscorpioidea, Xylopiaaethiopica, Allium sativum, Zinziber officinale and Cinnamomum zeylanicum) in stabilizing crude soyabean oil during accelerated storage was assessed. The phytochemical screening revealed the presence of phenols in all the spices except that of Allium sativum. Total phenolic content (TPC) and DPPH radical scavenging activity of the extracts varied significantly $(p<0.01)$ ranging from 1.34 to $17.72 \mathrm{~g}$ GAE/100 $\mathrm{g}$ and $18.91 \%$ to $96.39 \%$ respectively. Extract of Zinziber officinale, Olax subscorpioidea, Fagaramacrophylla, Eugenia caryophyllus and Xylopia parviflora, which offered the highest TPC, exhibited superior antioxidant activity with regard to the DPPH. Furthermore, the antioxidant effectiveness of the extracts and powders was assessed using crude soyabean oil (CSO) as the oxidation substrate. CSO samples stabilized with extracts at a concentration of $500 \mathrm{ppm}(\mathrm{w} / \mathrm{w})$ and powders at a concentration of $1000 \mathrm{ppm}$ were subjected to accelerated storage $\left(65^{\circ} \mathrm{C}\right.$, oven heating, 24 days, 8 h heating cycle per day), and analyzed periodically for the extent of oxidative alterations following the measurement of iodine and peroxide value. $C S O+B H T$ at $200 \mathrm{ppm}$ served as standards besides the control. Results reveal Zinziberofficinale, Cinnamomum zeylanicum, Scorodophleuszenkerii, Monodora myristica, Xylopiaaethiopica, Allium sativum, Fagara leprieurii extracts and powders and the powder of Pimpinella anisum to be potent an-
\end{abstract}

*Corresponding author. tioxidants for stabilization of crude soyabean oil.

Keywords: Natural Antioxidant; Cameroonian Spices; Lipids Oxidation; Stabilization; Soyabean Oil

\section{INTRODUCTION}

Nature has blessed aerobic organisms with an inner defense system that resists against oxidative damage due to reactive oxygen species (ROS). However, supplementing the natural defense mechanism with dietary antioxidants might offer better protection against the risk of certain diseases. Lipid peroxidation that results from the reaction between unsaturated fatty acids and molecular oxygen is a severe problem for the oil and fat industry. It not only deteriorates the quality of fats and fatty foods, bringing about chemical spoilage, but also produces free radicals and reactive oxygen species (ROS) which are reportedly associated with carcinogenesis, mutagenesis, inflammation, aging and cardiovascular diseases [1]. In order to overcome the stability problems of oils and fats, synthetic antioxidants such as butylatedhydroxyanisole (BHA), butylatedhydroxytoluene (BHT), ter-butyl hydroquinone (TBHQ) have been used as food additives. But recent reports reveal that these compounds may be implicated in many health risks, including cancer and carcinogenesis [2]. On the other hand, the use of plantbased antioxidant compounds in foods and preventive medicine is gaining a great deal of interest because of the potential health benefits [3]. It is well accepted that plants are the richest source of antioxidants. Among plants, spices are prominent because they contain a wide array of antioxidants including some vitamins, flavonoids, terpenoids, carotenoids, phytoestrogens, minerals, etc. which render them or their antioxidant components as preservative agents in food [4]. Polyphenolic com- 
pounds are commonly bound in both edible and inedible plants and they have been reported to have multiple biological functions such as antioxidant, anti-inflammatory, anti-cancer and anti-microbial activities [5]. In view of the beneficial effects and the vital role that natural antioxidants can play in human health, there is currently a greater demand for their isolation from more and more plant materials using effective extraction techniques. Following the new trends, in recent years, the use of plant extracts as antioxidant additives for improving the oxidative stability and shelf-life of vegetable oils and fats has also attracted a great deal of scientific interest. The antioxidant efficiency of methanolic extracts, essential oils and powders of some spices, herbs and agrowastes in vegetable oils has been proven [6-8]. Among spices, rosemary, sage, thyme, laurier, garlic and other spices have been determined as promising sources of natural antioxidants for stabilizing vegetable oils [6-11]. However, relatively less information is available on the stabilization of crude soyabean oil with spices produced and consumed in Cameroon.

Cameroon, being an agricultural country, is blessed with medicinally or economically important flora and agricultural crops. There are a number of spices for bioprospecting and screening of antioxidant components. This study is an attempt to investigate different indigenously available spices of Cameroon as potential sources of natural antioxidants and to appraise their efficacy for stabilizing crude soy oil during an accelerated storage.

\section{MATERIALS AND METHODS}

\subsection{Extraction of Plant Material}

Spices [Pimpinellaanisum (P.A), Scorodophleuszenkeii (S.Z), Xylopiaparviflora (X.P), Eugenia caryophyllus (E.C), Fagara leprieurii (F.L), Fagara macrophylla (F.M), Monodora myristica (M.M), Olaxsubscorpioidea (O.S), Xylopiaaethiopica (X.A), Allium sativum (A.S), Zinziberofficinale (Z.O) and Cinnamomum zeylanicum (C.Z)] and soyabeans were bought from vendors in a market located in Dschang, Menoua's Head Department and identified at the National Herbarium (Yaoundé, Cameroon).

Allium sativum and Zinziber officinale was peeled and dried in an oven at $55^{\circ} \mathrm{C}$ for $48 \mathrm{~h}$. The dried spices (Allium sativum, Zinziber officinale, Scorodophloeus zenkerii, Xylopiaparviflora, Eugenia caryophyllus, Fagaraleprieurii, Fagara macrophylla, Monodora myristica, Pimpinella anisum, Olaxsubscorpioidea, xylopiaaethiopica and Cinnamomum zeylanicum) were ground to pass through a $1 \mathrm{~mm}$ sieve. About $25 \mathrm{~g}$ of any spice was extracted into $600 \mathrm{ml}$ of methanol for $48 \mathrm{~h}$; extracts were regularly subjected to shaking at room temperature. The extracts were filtered and residue was again extracted with $300 \mathrm{ml}$ of methanol to ensure the complete extraction of phenolic compounds. Then, the filtrate was subjected to rotary evaporation at $65^{\circ} \mathrm{C}$ under reduced pressure for the removal of solvent. The extracts were weighed to calculate the yield and were stored at $4^{\circ} \mathrm{C}$ prior to further analysis.

\subsection{Extraction of Crude Soyabean Oil}

Dried soyabean was ground to pass through a $1 \mathrm{~mm}$ sieve. About $200 \mathrm{~g}$ of soyabean powder was extracted into $500 \mathrm{ml}$ of hexane for $48 \mathrm{~h}$ with regularly shaking at room temperature. The extract was filtered and the filtrate was subjected to rotary evaporation at $50^{\circ} \mathrm{C}$ under reduced pressure for the removal of the solvent. Crude soyabean oil was weighed to calculate the yield and was stored at $-18^{\circ} \mathrm{C}$ prior to further analysis.

\subsection{Qualitative Chemical Screening of the Methanolic Extracts}

The presence of major antioxidant secondary metabolite classes, namely, phenols, sterol and triterpenes was determined using common phytochemical methods as described by Harborne [12].

\subsection{Determination of Total Phenolics Content (TPC)}

Total phenols content was determined using the FolinCiocalteu colorimetric method as described by Gao et al. [13]. Plant extracts $(20 \mu \mathrm{l})$ were mixed in a test tube with $0.2 \mathrm{ml}$ of Folin-Ciocalteu reagent and $2 \mathrm{ml}$ of distilled water and incubated at room temperature for $3 \mathrm{~min}$. Following this, $1 \mathrm{ml}$ of $20 \%$ sodium carbonate was added to the mixture, re-incubated for $2 \mathrm{~h}$ at room temperature. The absorbance of the resulting blue color was measured using a quartz cuvet at $765 \mathrm{~nm}$. Gallic acid was used as standard and total phenols were expressed as gram gallic acid equivalents per $100 \mathrm{~g}$ of extracts.

\subsection{Preliminary Evaluation of the Antioxidant Activity by the DPPH Free Radical Scavenging Assay}

The radical scavenging ability was determined according to the method of Mensor et al. [14]. $1 \mathrm{ml}$ of $0.3 \mathrm{mM}$ alcoholic solution of DPPH was added to $2.5 \mathrm{ml}$ of the samples with different concentration of extracts. The samples were kept at room temperature in the dark and after $30 \mathrm{~min}$ the optic density was measured at $517 \mathrm{~nm}$. The optic density of the samples, the control and the blank, was measured in comparison with methanol. One synthetic antioxidant, butylatedhydroxytoluene (BHT) was used as positive control. The antiradical activity (AA) was determined by the following formula: 


$$
\mathrm{AA} \%=100-\left[\left(\mathrm{Abs}_{\text {sample }}-\mathrm{Abs}_{\text {empty sample }}\right) \times 100 / \mathrm{Abs}_{\text {control }}\right]
$$

\subsection{Evaluation of Antioxidant Efficacy of Extracts Using Crude Soyabean as Oxidation Substrate}

Antioxidant efficacy of extracts was determined according to the method of Iqbal and Bhanger [6]. Methanolic extracts of spices were added to preheated crude soyabean oil (at $50^{\circ} \mathrm{C}$ for $3 \mathrm{~h}$ ) at concentration of 500 $\mathrm{ppm}$. Synthetic antioxidants (BHT) were employed at the legal limit of $200 \mathrm{ppm}$ [15] to compare the efficacy of natural antioxidants. The dried extracts as well as the synthetic antioxidant were mixed with a minimum amount of absolute methanol using a vortex and added to $100 \mathrm{~g}$ oil before mixing again for $5 \mathrm{~min}$. All the samples $(100 \mathrm{~g})$ were placed in narrow-necked dark brown bottles without stoppers and stored in an electric oven at a fixed temperature of $65^{\circ} \mathrm{C}$. Control samples were also placed under the same storage conditions. Analyses were carried out after regular intervals of 4 days $(96 \mathrm{~h})$.

\subsection{Evaluation of Antioxidant Efficacy of Powders Using Crude Soyabean Oil as Oxidation Substrate}

Antioxidant efficacy of powders was determined according to the method of Iqbal and Bhanger [6] with few modifications. Powders of spices were directly added to preheated crude soyabean oil (at $50^{\circ} \mathrm{C}$ for $3 \mathrm{~h}$ ) at concentration of $1000 \mathrm{ppm}$. Synthetic antioxidants (BHT) were employed at the legal limit of $200 \mathrm{ppm}$ [15] to compare the efficacy of natural antioxidants. After mixing with a vortex $(10 \mathrm{~min})$, all the samples $(100 \mathrm{~g})$ were placed in dark brown coloured bottles with narrow necks and stoppers, and stored at ambient temperature for 3 days with regular shaking. After theses three days, stoppers where removed and the samples were stored in an electric oven at a fixed temperature of $65^{\circ} \mathrm{C}$. Control samples were also placed under the same storage conditions. Analyses were carried out after regular intervals of 4 days (96h).

\subsection{Measurement of Oxidation Parameters of Crude Soyabean Oil}

Determination of the iodine (IV) and peroxide value (PV) of stabilized and control crude soyabean oil samples were made following the AFNOR Official methods NFGA-203 and NFT 60-220 respectively [16].

\subsection{Statistical Analysis}

The tests were performed in triplicate and results are representative of the mean \pm standard deviations. All of these results have been submitted to the statistical analysis of variance (ANOVA) at $0.05 \%$ probability level. The Dunnett and Student-Newmann-Keuls tests were used to compare means using the software GraphpadInStat, 2000.

\section{RESULTS AND DISCUSSION}

\subsection{Extraction of Plant Materials}

The extract yield of antioxidative components from different spices varied over a wide range $8.25 \%$ to $41.27 \%$ (Table 1). The highest amounts were extracted from $\mathrm{Fa}$ gara leprieurii (41.27\%), followed by Xylopia aethiopica (39.75\%), Eugenia caryophyllus (32.75\%), Xylopia parviflora (29.5\%), Monodora myristica (27.75\%), Cinnamomum zeylanicum (25\%), Pimpinella anisum (21.25\%), Allium sativum (20.25\%), Fagara macrophylla (19.5\%), Olaxsubscorpioidea (12.5\%), Scorodophloeus zenkerii $(10.25 \%)$ and Zinziber officinale (8.25\%). Iqbal and Bhanger [6] investigated the extract yield of Garlic (Allium sativum) in pure methanol and found it to be $23.1 \%$. The amount of extractable components from Monodoramyristica, Cinnamomum zeylanicum, Scorodophloeus zenkerii and Fagara leprieurii using methanol was revealed in the literature as $23.5 \%, 8.4 \%, 9.2 \%$ and $26.2 \%$ respectively [17], from Eugenia caryophyllus and Zinziber officinale as $23.9 \%$ and $9.2 \%$ respectively [18] and from Olax subscorpioidea, Xylopia aethiopicaas $12.34 \%$ and $26.42 \%$ respectively [19]. Our present analysis revealed somewhat higher extract yields of the investigated plant materials.

Variations in the yield of extracts from different plant

Table 1. Yield of extracts and total phenolic contents.

\begin{tabular}{ccc}
\hline Plants & Yield $(\%)$ & $\begin{array}{c}\text { TPC }(\mathrm{g} \mathrm{GAE} / 100 \mathrm{~g} \\
\text { of extract) }\end{array}$ \\
\hline Scorodophloeus zenkerii & $10.25 \pm 1.06^{\mathrm{a}}$ & $3.25 \pm 0.00^{\mathrm{b}}$ \\
Xylopia parviflora & $29.5 \pm 0.00^{\mathrm{c}, \mathrm{d}}$ & $10.77 \pm 0.33^{\mathrm{f}}$ \\
Eugenia caryophyllus & $32.75 \pm 0.35^{\mathrm{d}}$ & $12.35 \pm 0.18^{\mathrm{g}}$ \\
Fagara leprieurii & $41.27 \pm 2.47^{\mathrm{e}}$ & $3.08 \pm 0.31^{\mathrm{b}}$ \\
Fagara macrophylla & $19.5 \pm 1.41^{\mathrm{b}}$ & $6.13 \pm 1.00^{\mathrm{d}}$ \\
Monodora myristica & $27.75 \pm 0.35^{\mathrm{c}}$ & $3.22 \pm 0.59^{\mathrm{b}}$ \\
Pimpinella anisum & $21.25 \pm 1.76^{\mathrm{b}}$ & $2.96 \pm 0.17^{\mathrm{b}}$ \\
Olax subscorpioidea & $12.5 \pm 3.53^{\mathrm{a}}$ & $8.39 \pm 0.53^{\mathrm{e}}$ \\
Xylopia aethiopica & $39.75 \pm 2.47^{\mathrm{e}}$ & $2.74 \pm 0.37^{\mathrm{b}}$ \\
Allium sativum & $20.25 \pm 2.47^{\mathrm{b}}$ & $1.34 \pm 0.05^{\mathrm{a}}$ \\
Cinnamomum zeylanicum & $25 \pm 1.41^{\mathrm{b}, \mathrm{c}}$ & $4.31 \pm 0.46^{\mathrm{c}}$ \\
Zinziber officinale & $8.25 \pm 0.35^{\mathrm{a}}$ & $17.72 \pm 0.72^{\mathrm{h}}$ \\
\hline
\end{tabular}

Values with different letters differ significantly $\mathrm{p}<0.05$. 
materials might be attributed to the availability of different extractable components, defined by the chemical composition of the plant, nature of the soil and agroclimatic conditions [20]. Among other parameters, the effectiveness of the extracting solvent to dissolve endogenous compounds might also be a contributing factor.

\subsection{Extraction of Crude Soyabean Oil}

The oil yield of soyabeans extracted with hexane was $18.3 \%$. This value was in agreement with the classification of ITERG [21] where soyabeans are classified as oleaginous with an oil yield less than $35 \%$.

\subsection{Qualitative Chemical Screening of the Methanolic Extracts}

The qualitative analysis revealed the presence of at least two classes of secondary metabolites (phenols, triterpenes and sterols) (Table 2) in all plant extracts, except that of Allium sativum and Scorodophloeus zenkerii. Phenols have been detected in all plants, excepted that of Allium sativum. The presence of phenols in almost all the spices could be explained by the fact that they are mostly distributed in plants due to their important function in defense mechanisms [22]. Some of these results are in accordance with those obtained by Voukeng [17], Fankam et al. [19], N'Guessan et al. [23] and Lacmata et al. [24] after a chemical screening of the same plants. The differences in composition of certain plants observed in the work of other authors might be attributed to the environmental variations, age of the plant, extraction process, nature of the extraction solvent and part of the plants used [12]. Though the detection of such metabo-

Table 2. Phytochemical composition of the plant extracts.

\begin{tabular}{|c|c|c|c|}
\hline plants extracts & Phenols & Triterpenes & Sterols \\
\hline Scorodophloeus zenkerii & + & - & - \\
\hline Xylopia parviflora & + & + & - \\
\hline Eugenia caryophyllus & + & + & + \\
\hline Fagara leprieurii & + & + & - \\
\hline Fagara macrophylla & + & + & - \\
\hline Monodora myristica & + & + & - \\
\hline Pimpinella anisum & + & - & + \\
\hline Olax subscorpioidea & + & + & - \\
\hline Xylopia aethiopica & + & - & + \\
\hline Allium sativum & - & - & - \\
\hline Cinnamomum zeylanicum & + & + & - \\
\hline Zinziber officinale & + & + & - \\
\hline
\end{tabular}

lites does not automatically predict the antioxidant activity of a plant extract, it has clearly been demonstrated that several compounds belonging to the investigated classes of metabolites showed antioxidant activities $[8,25]$.

\subsection{Total Phenolic Content (TPC)}

The amount of phenolics, measured by Folin-Ciocalteu method, varied widely in spices materials and ranged from 1.34 to $17.72 \mathrm{~g}$ of gallic acid equivalents (GAE) /100 g of extract (Table 1). Eugenia caryophyllus and Zinziber officinale with respective mean values of 12.35 and $17.72 \mathrm{~g} / 100 \mathrm{~g}$ were found to contain the highest levels while a low level $(1.34 \mathrm{~g} / 100 \mathrm{~g})$ was found in Allium sativum. From a comparative view point, the values found with the extracts of Monodoramyristica, and Allium sativum were higher than those reported by George and Osioma [26] with respective mean values of 2.93 and $0.41 \mathrm{mg}$ GAE/g dw. Those found with the extracts of Xylopiaaethiopica, Fagara leprieurii, Xylopiaparviflora, Scorodophloeus zenkerii and Eugenia caryophyllus were less than those reported in the literature $[11,27,28]$ with respective mean values of 5.86, 5.05, $51.83 \mathrm{mg} \mathrm{ECA} / \mathrm{g}$ of plant, 4.46 and $8.96 \mathrm{~g} \mathrm{GAE} / 100 \mathrm{~g}$ dw. Significant differences between the results were likely due to genotopic and environmental differences (namely climate, location, temperature, fertility, diseases and pest exposure) within species, choice of parts tested, time of taking samples and determination methods [29, 30]. Several researchers have used this assay to determine total phenolics and often established a good linear correlation between the "total phenolic profile" and antioxidant activity.

\subsection{DPPH Free Radical Scavenging Assay}

In the present study, we also investigated the free radical scavenging capacity of our extracts. The DPPH radical scavenging activity of all the extracts increased in a concentration dependent manner (Figure 1). Extracts of Zinziber officinale, Xylopia parviflora, Eugenia caryophyllus and Olax subscorpioidea exhibited the highest antioxidant activity on DPPH free radicals, similar to that of $B H T$, range from $43.57 \%$ (at $6.25 \mu \mathrm{g} / \mathrm{ml}$ ) to $95.34 \%$ (at $200 \mu \mathrm{g} / \mathrm{ml}$ ), while the lowest antioxidant activity was observed in the extract of Allium sativum, ranging from $20 \%$ (at $6.25 \mu \mathrm{g} / \mathrm{ml}$ ) to $46.46 \%$ (at $200 \mu \mathrm{g} / \mathrm{ml}$ ). We also observed that the extracts showing greater amounts of total phenolics also exhibited higher antioxidant activity while the extract of Allium sativum, which showed the lowest total phenolics exhibited the lowest antioxidant activity. These results are in line with the findings of Velioglu et al. [31] who reported that extracts with higher total phenolic content also showed strong activity 


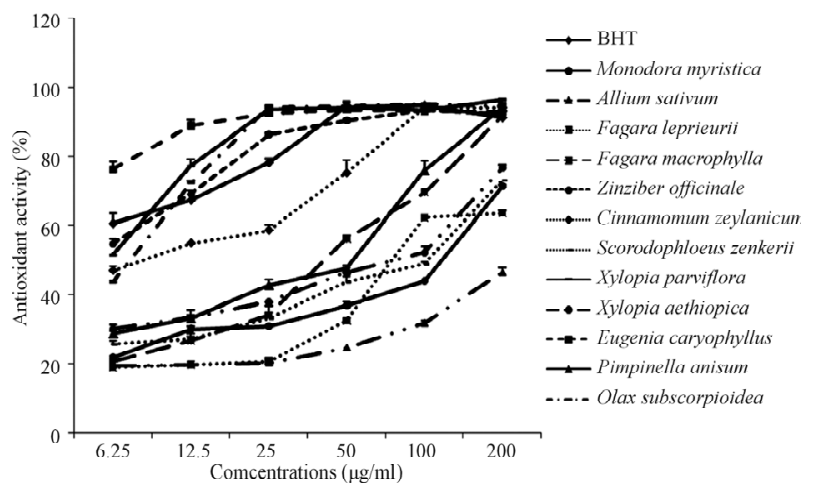

Figure 1. Scavenging effects of spices extracts on DPPH radical.

against linoleic acid peroxidation. So, the antioxidant activity of theses extracts might be attributed to the presence of phenols. Moreover, the phytochemical screening showed the presence of triterpenes and sterols in some of the spices extracts which have been proven to have good antioxidant properties $[8,32]$. These compounds would contribute to the antioxidant properties observed in theses spices. The results obtained in this study are not far to those found in the literature: $90.1 \%$ for Zinziber officinale [10]; $90.55 \%$ and $48.82 \%$ for Xylopia parviflora and Xylopia aethiopicarespectively [28]; 70\% for Eugenia caryophyllus [18]; 50\% for Allium sativum [33]; $94.42 \%$ for essential oils of Cinnamomum zeylanicum [34] and 90\% for Pimpinella anisum [35]. The differences observed might be attributed to the nature of the extraction solvent, to the part of plant used and also to the method used.

\subsection{Antioxidant Efficacy of Extracts Using Crude Soyabean Oil as Oxidation Substrate}

\subsubsection{Iodine Value}

After preliminary assessment of antioxidant efficacy of different extracts, the effectiveness of the extracts towards the stabilization of crude soyabean oil was also examined. The iodine values of the stabilized and control (without extract) crude soyabean oil, over an incubation period of 24 days at $65^{\circ} \mathrm{C}$, is shown in Figure 2. It is observed that the iodine value decreases gradually during storage. The rate of decrement in oils without antioxidants was higher than that in oil containing synthetic and natural antioxidants. A decreasing of the iodine value of oils is generally attributed to the destruction of the fatty acid double bonds caused by oxidation process [36]. It is clear from the results that the addition of both the synthetic antioxidant at a concentration of $200 \mathrm{ppm}$ and methanolic extracts of Xylopiaparviflora, Zinziberofficinale, Cinnamomum zeylanicum, Scorodophloeus zenkerii, Monodora myristica, Fagara leprieurii, Allium Sativum and Xylopia aethiopica at 500 ppm have inhi-

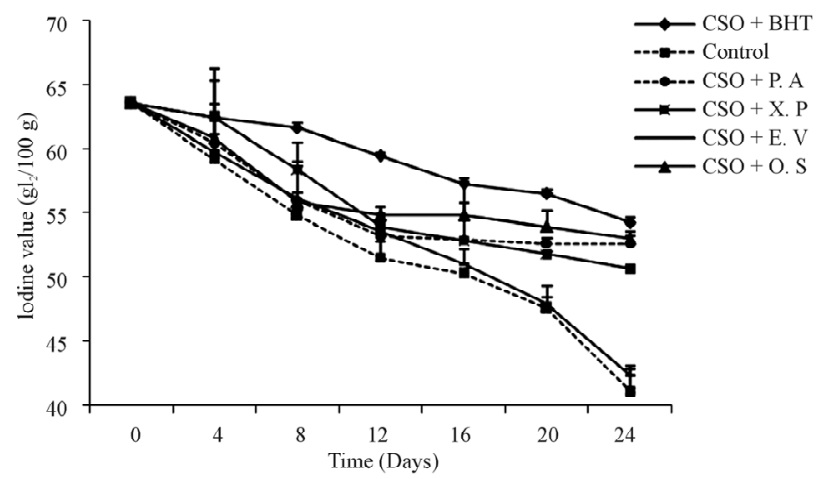

(a)

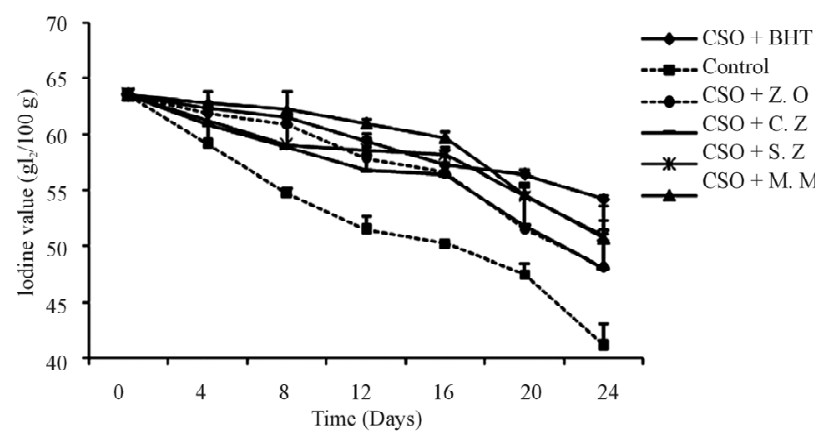

(b)

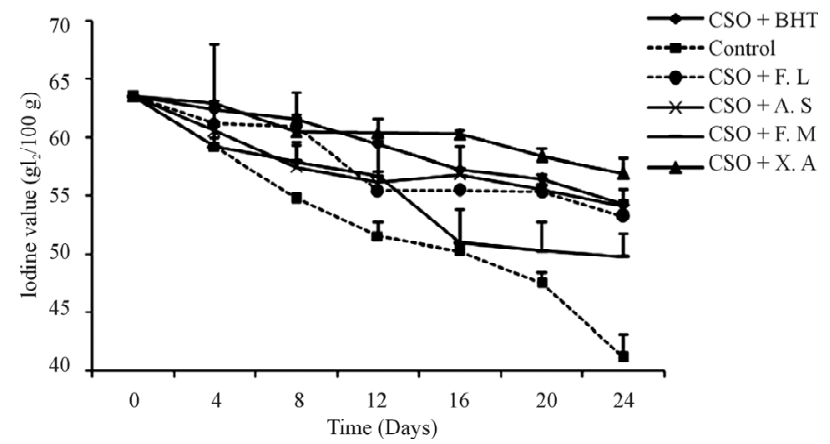

(c)

Figure 2. (a)-(c) Effect of heating time on iodine values of crude soyabean oil treated with different antioxidants.

bited the oxidation in crude soyabean oil significantly (p $<0.05)$ as compared with the control. The antioxidant activity of these extracts might be attributed to phenols, triterpenes or sterols. In addition to a few phenol content of the extract of Allium sativum, its antioxidant activity might be also due to other compounds. It has been proven that Allium sativum is rich in selenium and organosulfur compounds, which have pronounced antioxidant activity [37]. These compounds might contribute to the antioxidant activity of this extract. The rapid decrease of the iodine value of certain stabilized samples after a certain period of storage would be due to the volatilization of natural antioxidant under heating. It has been proven that all antioxidants remain effective over a specific period of time, and with the passage of time their 
effectiveness decreases until they finally become ineffective [38]. Such antioxidants end or at least interrupt oil and fat deterioration in the early stages, thus delaying the onset of the reaction and are found to be efficient only up to a specific period. It may be hypothesized that phenolic antioxidants inhibit lipid peroxidation at the cost of their own life and thus decompose and deteriorate themselves with the course of time [39]. Result found in this study proved that the above cited extracts inhibited the alteration of fatty acids double bonds in crude soyabean oil, a result which is in accordance with that obtained by Kahouli [8]. This author showed that the ethanolic extracts and essential oils of the spices Laurusnobilis, Rosmarinus offininalis and Origanum majorana at 1\%, limit the degradation of the fatty acid $\mathrm{C} 18: 2$ and $\mathrm{C} 18: 3$ in canola oil during a 5 days storage at $120^{\circ} \mathrm{C}$ and $180^{\circ} \mathrm{C}$. The similar result were also obtained by Al-Dalain et al. [40] which showed that essential oil of ginger, rosemary and fernel inhibit the alteration of fatty acid double bonds in sunflower oil during heating and storage.

\subsubsection{Peroxide Value}

The peroxide value, which measures hydroperoxide products of the oils [41], is a good indicator of the oxidation state of the oils. The peroxide values of the stabilized and control (without extract) crude soyabean oil, over an incubation period of 24 days at $65^{\circ} \mathrm{C}$ is shown in Figure 3. A typical pattern in the rise of Peroxide value was observed for almost all the oil treatments under storage conditions but, after a certain period, a decreasing of the peroxide values of control, $C S O+E C$ and CSO + FM was observed. The control had the highest Peroxide value among all the oil treatments, followed by CSO +EC and CSO + FM showing a higher degree of oxidation. The lowest Peroxide value was observed in $C S O+B H T$, showing a good stability of the oil due to the strong antioxidant efficacy of BHT at $200 \mathrm{ppm}$. Through methanolic extract, Xylopiaparviflora, Zinziber officinale, Cinnamomum zeylanicum, Scorodophloeus zenkerii, Monodora myristica, Fagaraleprieurii, Allium sativum and Xylopia aethiopica at 500 ppm were found to be the most effective in retarding the peroxidation of crude soyabean oil treatments, whereas others were relatively less effective. A significance difference $(\mathrm{p}<0.05)$ was observed between the control and $\mathrm{CSO}+\mathrm{BHT}, \mathrm{CSO}+\mathrm{X.P}, \mathrm{CSO}+\mathrm{Z} . \mathrm{O}, \mathrm{CSO}+\mathrm{C.Z}$, $\mathrm{CSO}+$ S.Z, CSO + M.M, CSO + F.L, CSO + A.S and CSO $+X$.A, showing an antioxidant potential of these extracts and synthetic antioxidant. The antioxidant efficacy of theses spices might be attributed in part to the presence of phenols, monoterpenes and sterols. Selenium and organosulphur compounds of Allium sativum might also be implicated in it antioxidant activity [37]. A slow rise in the Peroxide value of the above cited oil treatments,

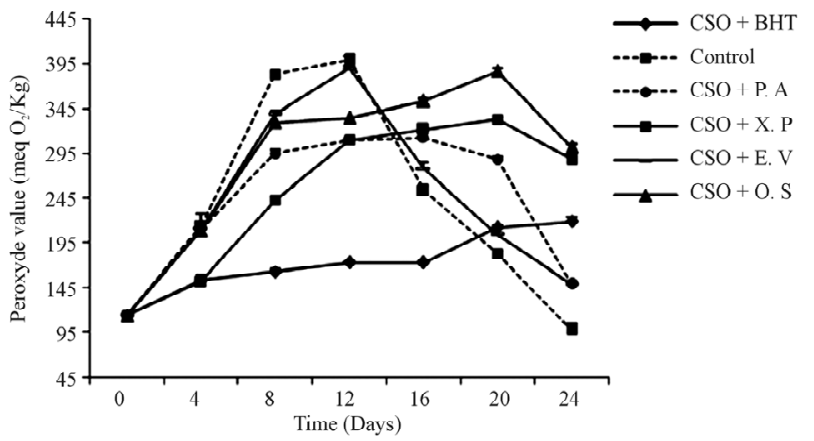

(a)

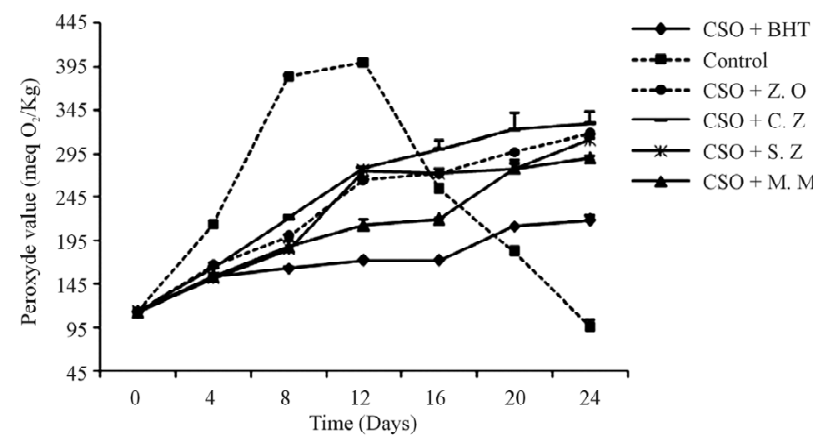

(b)

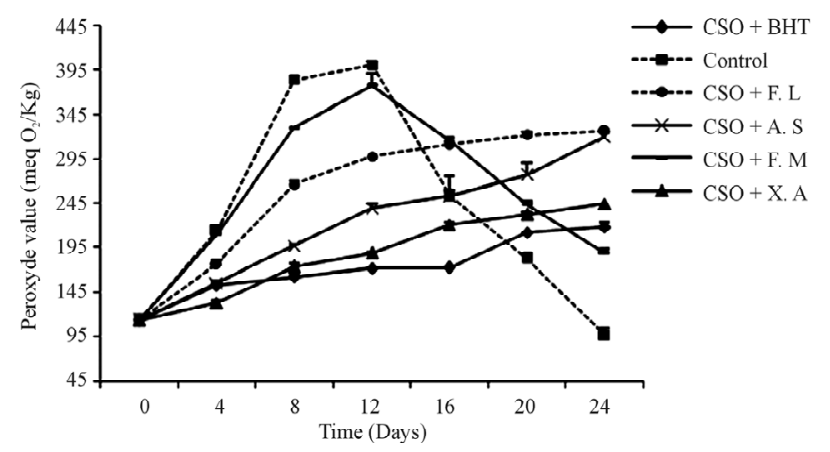

(c)

Figure 3. (a)-(c) Effect of heating time on peroxide values of crude soyabean oil treated with different antioxidants.

as compared to those of the control, clearly indicated a good antioxidant activity of the extracts and BHT. This increasing in Peroxide value might be due to the fact that antioxidants remain effective over a specific period of time, and with the passage of time their effectiveness decreases until they finally become ineffective [38]. The decrease in peroxide value of certain oil treatments observed in Figure 3 after a certain period might be related to the observation of Shahidi et al. [42], who suggested that a decrease in peroxide value after long heating times may be due to volatilization of some breakdown products of lipid hydroperoxides, formed in the primary stages of oxidation. The good antioxidant activity obtained with the extract of Allium sativumin crude soyabean oil confirm the result obtained by Iqbal and Bhanger [6] with the same extract in sunflower oil. Apart from the extract 
of Zinziber officinale, where the antioxidant activity in crude soyabean oil is related to the total phenolic compounds, it is clear for the other extracts that their antioxidant activity in oil is not correlated to their total phenolic content. Their antioxidant potential would be completed by the presence of other active compounds such as monoterpenes and sterols. Findings from our present study are also supported in the literature where it is stated that plant extracts may sometimes exhibit contradictory antioxidant activity when used under different conditions [43]. The results found in this study prove that the above cited extracts inhibit the peroxidation of crude soyabean oil. The same results were reported by Sultana et al. [44] in corn oil by the methanolic extracts of some agrowastes, and by Anwar et al. [45] in sunflower oil by the $100 \%$ and $80 \%$ methanol extracts from barley seeds.

\subsection{Antioxidant Efficacy of Plant Powders Using Crude Soya Oil as Oxidation Substrate}

\subsubsection{Iodine Value}

After assessment of antioxidant efficacies of different extracts in crude soyabean oil, the effectiveness of their powders (at $1000 \mathrm{ppm}$ ) towards the stabilization of crude soyabean oil was also examined. The iodine values of the stabilized and control (without powders) crude soyabean oil, over an incubation period of 24 days at $65^{\circ} \mathrm{C}$ is shown in Figure 4. It is observed that the iodine value decreases gradually during storage. The rate of decrement in the control, CSO + O.S and CSO + X.A was higher than that of other samples, but this decrement was higher in $C S O+O . S$ and $C S O+X . A$ than in the control. This might be explained by the presence in these spices powders of prooxidants compounds such as metals (iron and copper) which have been proved to be good catalysers of oxidation reactions [46]. Apart from CSO + O.S and $C S O+X . A$ all the stabilized samples significantly improved an appreciable stability for at least 12 days of storage when compared with the control. The samples $\mathrm{CSO}+\mathrm{BHT}, \mathrm{CSO}+$ P.A, CSO + E.C, CSO + C.Z, CSO + $M . M, C S O+A . S, C S O+F . L$ and $C S O+F . M$ were more stable than all others. The stability observed might be due to the action of liposoluble active metabolites with antioxidant properties, which include monoterpenes, sterols and certain phenols. The results of the chemical screening showed the presence of these classes of metabolites in certain extracts. It can be hypothesized that during storage, antioxidant compounds by a mechanism of infusion migrate from plant powders to oil. The rapid decrement of the iodine value observed after a period of treatment might be attributed to the volatilization of antioxidant compounds from oil [47]. Certain phenols and monoterpenes are volatile compounds and have been proved to volatilize rapidly during heating. Results ob-

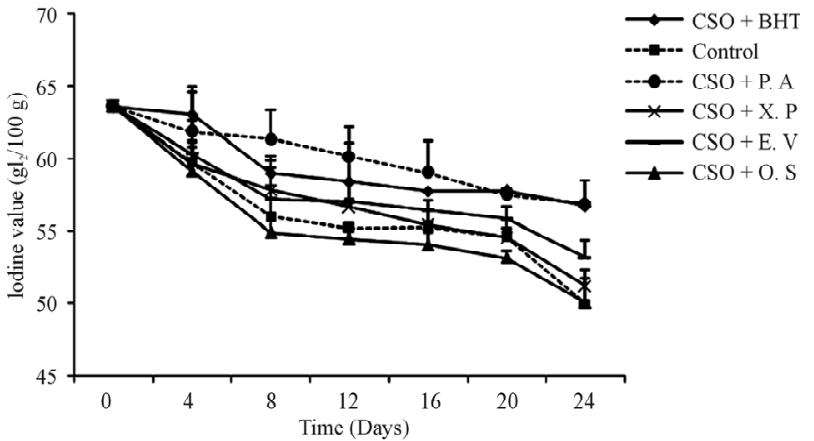

(a)

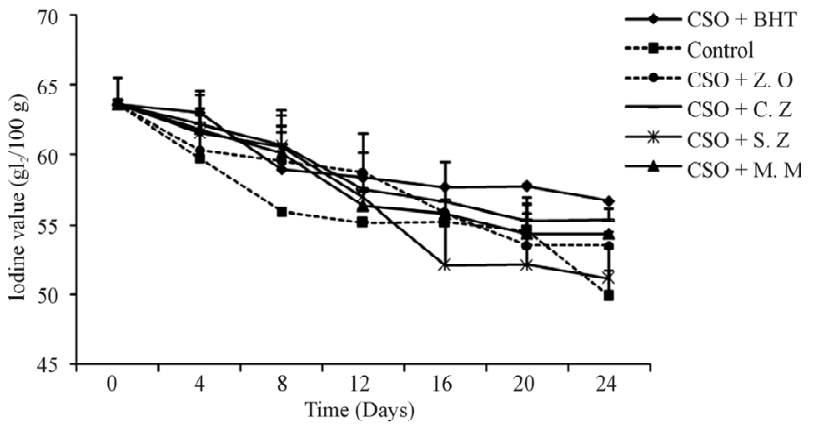

(b)

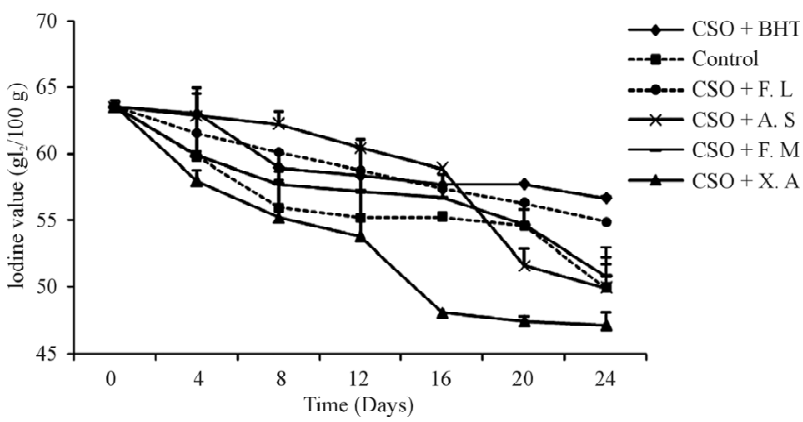

(c)

Figure 4. (a)-(c) Effect of heating time on iodine values of crude soyabean oil treated with different antioxidants.

tained in this study, show that some spice powders could reduce the alteration of fatty acid double bonds to justify those obtained by Kahouli [8]. In fact, this author showed that powders of the spices Laurusnobilis, Rosmarinus offininalis and Origanummajorana at $1 \%$ inhibit the alteration of fatty acid double bonds in canola oil during a storage of 5 days at $120^{\circ} \mathrm{C}$ and $180^{\circ} \mathrm{C}$.

\subsubsection{Peroxide Value}

The peroxide value of stabilized (with plant powders at $1000 \mathrm{ppm}$ ) and control (without powder) crude soyabean oil samples over a storage of 24 days at $65^{\circ} \mathrm{C}$ is shown in Figure 5. A rise of peroxide value is observed in all the samples during at least the 12 first days. After a certain period, a decrement in peroxide value is observed in all the samples except that of CSO $+B H T, C S O+P . A$ and 


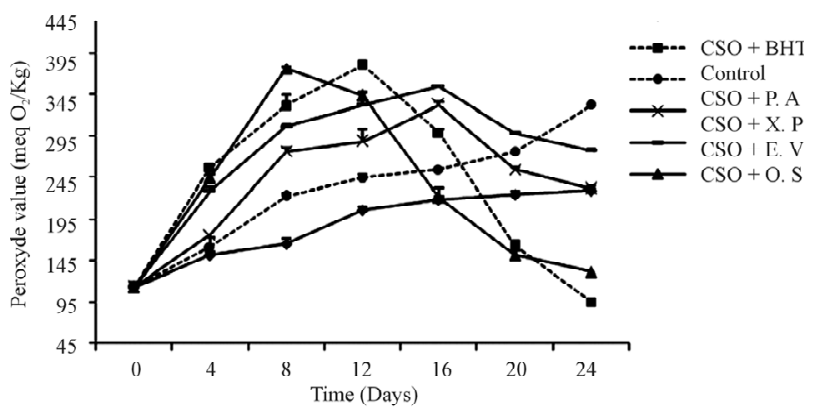

(a)

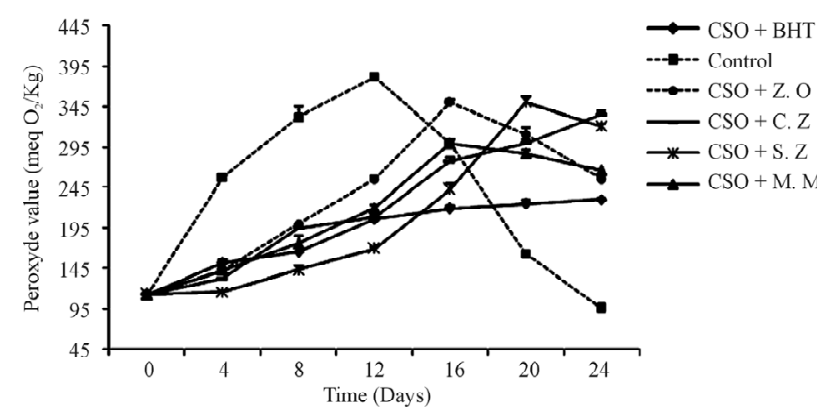

(b)

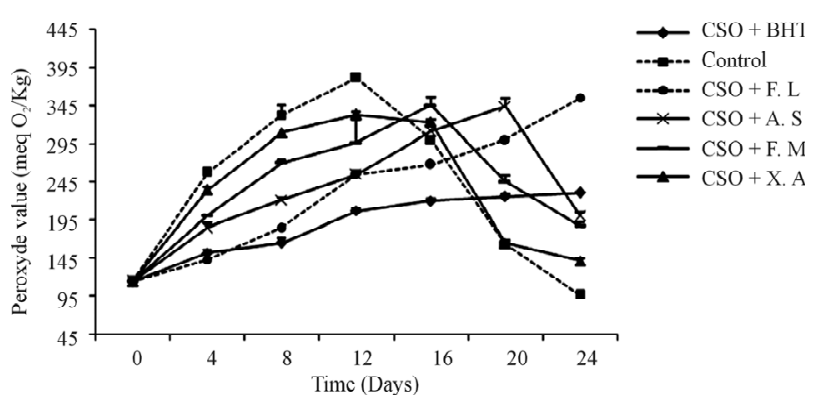

(c)

Figure 5. (a)-(c) Effect of heating time on peroxide values of crude soyabean oil treated with different antioxidants.

CSO + F.L. The control and CSO + O.S have presented the highest value of peroxide showing that these samples were more oxidized. The lowest values of peroxide were observed in CSO + BHT, CSO + P.A and CSO + F.L, showing a good stability due to the antioxidant property $B H T$ and the powder of these plant materials. Good stability was also observed in CSO + Z.O, CSO + C.Z, $C S O+S . Z, C S O+M . M, C S O+A . S$ for at least 16 days of storage, but from the $16^{\text {th }}$ forward, their peroxide value increased considerably and began to decline. This might be explained by a volatilization of antioxidant compounds. In fact, it might be hypothesized that after volatilization of antioxidant compounds [47], oil samples oxidized more rapidly and, when the content in hydroperoxides is very high, the primary oxidation products which are hydroperoxides break down in secondary oxidation products which can be volatiles or non volatiles [42]. The high oxidation state observed in stabilized samples $C S O+O . S$ and $C S O+X . A$ might be attributed to the presence in the powdered samples of prooxydant compounds such as metals, which are known to be good catalysers of oxidation reactions [46]. The results obtained in this study which show that some spice powders at $1000 \mathrm{ppm}$, could reduce the peroxide formation justify the results obtained by Kahouli [8]. In fact, this author showed that powders of the spices Laurusnobilis, Rosmarinus offininalis and Origanum majorana at $1 \%$ inhibit the alteration of fatty acid double bonds in canola oil during a storage of 5 days at $120^{\circ} \mathrm{C}$ and $180^{\circ} \mathrm{C}$. It is known that the alteration of fatty acid double bond is due to their attack by free radicals

\section{CONCLUSION}

The antioxidant activity of methanolic extracts (at 500 ppm) and powders (at $1000 \mathrm{ppm}$ ) tested in crude soyabean oil reveal Zinziber officinale, Cinnamomum zeylanicum, Scorodophleus zenkerii, Monodora myristica, Xylopiaaethiopica, Allium sativum, Fagara leprieurii extracts and powders, in addition to the powder of Pimpinella anisum to be potent antioxidants for stabilization of crude soyabean oil. However, this antioxidant effectiveness was dependent not only on the action of phenols but also on that of monoterpenes and sterols. These extracts were found to be quite effective towards suppressing the primary oxidation products and presservation of fatty acid double bonds in the tested oil. This suggests that these plants might be explored as viable sources of potent antioxidants for the protection of vegetable oils from oxidation.

\section{REFERENCES}

[1] Sikwese, F.E. and Duodu, K.G. (2007) Antioxidant effects of crude phenolic extracts from sorghum bran in sunflower oil in the presence of ferric ions. Food Chemistry. 104, 324-331. doi:10.1016/j.foodchem.2006.11.042

[2] Prior, R.L. (2004) Absorption and metabolism of anthocyanins: Potential health effects. In: Meskin, M.S., Bidlack, W.R., Davies, A.J., Lewis D.S. and Randolph R.K., Eds., Phytochemicals: Mechanisms of Action, CRC Press, Boca Raton, 1-19.

[3] Hussain, A.I., Anwar, F., Sherazi, S.T.H. and Przybylski, R. (2008) Chemical composition, antioxidant and antimicrobial activities of basil (Ocimum basilicum) essential oils depends on seasonal variations. Food Chemistry, 108, 986-995. doi:10.1016/j.foodchem.2007.12.010

[4] Calucci, L., Pinzono, C., Zandomeneghi, M. and Capocchi, A. (2003) Effect of gamma irradiation on the free radical and antioxidant contents in nine aromatic herbs and soices. Journal of Agricultural and Food Chemistry, 51, 927-934. doi:10.1021/jf020739n

[5] John, A.M. and Grohmann, K. (2001) Phenols in citrus peel by products, concentration of hydroxycinnamates and polymethoxylated flavones in citrus peel molasses. 
Journal of Agricultural and Food Chemistry, 49, 32683273. doi:10.1021/jf010011r

[6] Iqbal S. and Bhanger M.I. (2007) Stabilization of sunflower oil by garlic extract under accelerated storage. Food Chemistry, 100, 246-254. doi:10.1016/j.foodchem.2005.09.049

[7] Raza, S.A., Rehman, A., Adnan and Qureshi F. (2009) Comparison of antioxidant activity of essential oil of Centella asiatica and butylated hydroxyanisole in sunflower oil at ambient conditions. Biharean Biologist, 3, 71-75.

[8] Kahouli, I. (2010) Effet antioxydant d'extraits de plantes (Laurus nobilis L., Rosmarinus officinalis, Origanum majorana, Oléa europea L.) dans l'huile de canola chauffée. Thèse de Master, Université Laval Québec, 16-52.

[9] Wyen, D.V., Takacsova, M., Jakubik, T. and Dang, M. (2000). Antioxidant effects of thyme in rape seed oil. Biologia Bratislava, 55, 277-281.

[10] Stoilova, I., Krastanov, A., Deney, P. and Gargova, S. (2007) Antioxydant activity of a ginger extract (Zinziberofficinale). Food Chemistry, 102, 764-770. doi:10.1016/j.foodchem.2006.06.023

[11] Bouba, A.A., Njintang, Y.N., Scher, J. and Mbofung, C.M.F. (2010) Phenolic compounds and radical scavenging potential of twenty cameroonian spices. Agriculture and Biology Journal of North America, 1, 213-224. doi:10.5251/abjna.2010.1.3.213.224

[12] Harbone, J.B. (1973) Phytochemical methods: A guide to modern techniques of plant analysis. Chapman and Hall Ltd., London, $116 \mathrm{p}$.

[13] Gao, X., Ohlander, M., Jeppsson, N., Björk, L. and Trajkovski, V. (2000) Changes in antioxydant effects and their relationship to phytonutrients in fruits of sea buckthorn (Hippophaerhamnoides L) during maturation. Journal of Agricultural and Food Chemistry, 48, 1485-1490. doi:10.1021/jf991072g

[14] Mensor, L.L., Menezez, F.S., Leitao, G.G., Reis, A.S., Dos Santos, T.C., Coube, C.S. and Leitao, S.G. (2001) Screning of Brazilian plant extracts for antioxidant activity by the use of DPPH free radical method. Phytotherapy Research, 15, 127-130. doi:10.1002/ptr.687

[15] Duh, P.D. and Yen, G.C. (1997) Antioxidant efficacy of methanolic extracts of peanut hulls in soybean and peanut oils. Journal of American Oil Chemists Society, 74, 745748.

[16] AFNOR (Association Française de Normalisation) (1981) Recueil des normes françaises. Corps gras, graines oléagineuses, produits dérivés. 2nd Edition, AFNOR, Paris, $438 \mathrm{p}$.

[17] Voukeng (2011) Activités antibactériennes de onze épices Camerounaises et leurs effets en association avec les antibiotiques sur les bactéries Gram negative multirésistantes in vitro. Thèse de Master II, Université de Dschang, Dschang, $71 \mathrm{pp}$.

[18] Khalaf, N.A., Shakia, A.K., Othman, A.A., Agbar, Z.E. and Farah, H. (2008) Antioxydant Activity of some common plants. Turkish Journal of Biology, 32, 51-55.

[19] Fankam, G.A., Kuete, V., Voukeng, K.I., Kuiate, J.R. and
Pages, J.M. (2011) Antibacterial of selected Cameroonian spices and their synergistic effets with antibiotic against Multidrug-resistant phenotypes. Complementary and Alternative Medicine, 11, 104. doi:10.1186/1472-6882-11-104

[20] Hsu, B., Coupar, I.M. and Ng, K. (2006) Antioxidant activity of hot water extract from the fruit of the Doum palm, Hyphaenethebaica. Food Chemistry, 98, 317-328. doi:10.1016/j.foodchem.2005.05.077

[21] Institut des Corps gras (ITERG) (2010) Huiles végétales: Guide d'aide à l'application des meilleures technologies disponibles (MTD), Réseau Mixte Technologique. 73 p.

[22] Muanda, F.N. (2010) Identification de polyphénols, évaluation de leur activité antioxydante et étude de leurs propriétés biologiques. Thèse de Doctorat, Université Paul Verlaine-Metz, 55-86.

[23] N'Guessan, H.A., Déliko, D.C.E., Békro, M.J.A. and Békro, Y.A. (2011) CCM D'extraits selectifs de 10 plantes utilisees dans le traitement traditionnel de l'hypertension arterielle en cote d'ivoire. European journal of Scientific Research, 4, 575-585.

[24] Lacmata, S.T., Kuete, V., Dzoyem, J.P., Tankeo, S.B., Ngo, T.G., Kuiate, J.R. and Pages, J.M. (2012). Antibacterial activities of selected cameroonian plants and their synergistic effects with antibiotics against bacteria expressing MDR phenotypes. Complementary and Alternative Medicine, 2012, 1-11.

[25] Guillen, M.D. and Manzanos, M.J. (1998) Study of the composition of the different parts of a Spanish Thrus vulgaris L. plant. Food Chemistry, 63, 373-383. doi:10.1016/S0308-8146(98)00013-2

[26] Georges, B.O. and Osioma, E. (2011) Phenolic content and total antioxidant capacity of local spices in Nigeria. African Journal of Food Science, 5, 741-746.

[27] Wojdylo, A., Oszmianski, J. and Czemerys, R. (2007) Antioxidant activity and phenolic compounds in 32 selected herbs. Food Chemistry, 105, 940-949. doi:10.1016/j.foodchem.2007.04.038

[28] Etoundi, C.B., Oben, J., Kuate, D. and Ngondi, J.L. (2010) Anti-amylase, anti-lipase and antioxidant effects of aqueous extracts of some Cameroonian spices. Journal of $\mathrm{Na}$ tural Product, 3, 165-171

[29] Kim, I. and Choe, E. (2004) Oxidative stability and antioxidant content changes in roasted and bleached sesame oil during heating. Food Science and Biotechnology, 13, 762-767

[30] Shan, B., Cai, Y.Z., Sun, M. and Corke, H. (2005) Antioxydant capacity of 26 spices extracts and characterization of their phenolic constituents. Journal of Agricultural and Food Chemistry, 53, 7749-7759. doi:10.1021/jf051513y

[31] Velioglu, M.S.G., Gao, L. and Oomah, B.D. (1998) Antioxidant activity and total phenolics in selected fruits, vegetables, and grain products. Journal of Agricultural and Food Chemistry, 46, 4113-4117. doi:10.1021/jf9801973

[32] Schiber, A., Berardini, N. and Carle, R. (2003) Identification of flavonol and xanthol glycosides from mango peels 
by HPLC. Journal of Agricultural and Food Chemistry, 51, 5006-5011.

[33] Othman, S.F.C., Idid, S.Z., Koya, S.K., Rehan, A.M. and Kamarudin, K.R. (2011) Antioxydant study of garlic and Red Onion: A comparative study. Pertanika Journal of Tropical Agricultural Science, 34, 253-261.

[34] Schmidt, E., Jirovetz, L., Buchbauer, G., Eller, G.A., Stoilova, I., Krastanov, A., Stoyanova, A., Geissler, M. (2006) Composition and antioxidant activities of the essential oil of cinnamon (Cinnamomum zeylanicum Blume) leaves from Sri Lanka. Journal of Essential Oil Bearing Plants, 9, 170-182. doi:10.1080/0972060X.2006.10643490

[35] Nickavar, B. and Abolhasani, F.A. (2009) Screening of antioxydant properties of seven umbelliferae fruits from Iran. European Journal of Pharmaceutical Sciences, 22, 30-35.

[36] Tynek, M., Hazuka, Z., Pawlowicz, R. and Dudek, M. (2001) Changes in the frying medium during deep-frying of food rich in proteins and carbohydrates. Journal of Food Lipids, 8, 251-261. doi:10.1111/j.1745-4522.2001.tb00200.x

[37] Yin, M., Hwang, S. and Chan, K. (2002) Nonenzymatic antioxidant activity of four organosulfur compounds derived from garlic. Journal of Agricultural and Food Chemistry, 50, 6143-6147. doi:10.1021/jf0204203

[38] Laandrault, N., Pouchert, P., Ravel, P., Gase, F., Cros, G. and Teissedro, P,-L. (2001) Antioxidant activities and phenolic level of French wines from different varieties and vintages. Journal of Agricultural and Food Chemistry, 49, 3341-3343. doi:10.1021/jf010128f

[39] Anwar, F., Bhanger, M.I. and Kazi, T.G. (2000) Activity of phenolic antioxidants on the storage ability of soybean cooking oil. Pakistan Journal of Biological Sciences, 3,
1333-1335.

[40] Al-Dalain, S.Y.A., Al-Fraihat, A.H. and Al Kassabeh, E.T. (2011) Effect of aromatic plant essential oils on oxidative stability of sunflower oil during heating and storage. Pakistan Journal of Nutrition, 10, 864-870.

[41] Mc Ginely, L. (1991) Analysis and quality control for processing and processed fats. In: Rossell, J.B. and Pritchard, J.L.R., Eds., Analysis of Oilseeds, Fats and Fatty Foods, Elsevier Applied Science, New York, 460-470.

[42] Shahidi, F., Janitha, P.K. and Wanasundara, P.D. (1992) Phenolic antioxidants. Critical Reviews in Food Science and Nutrition, 32, 67-103. doi:10.1080/10408399209527581

[43] Economou, K.D., Oreopoulou, V. and Thomopoulos, C.D. (1991) Antioxidant activity of some plant extracts of the family Labiateae. Journal of the American Oil Chemists Society, 68, 109-113. doi:10.1007/BF02662329

[44] Sultana, B., Farooq, A., Muhammad, R.A. and Shahzad, A.S.C. (2008) Antioxydant potential of extracts from diffrent agrowastes: Stabilization of corn oil. Grasas $Y$ Aceites, 59, 205-217.

[45] Anwar, F., Qayyum, H.M.A., Hussain, A.L. and Iqbal, S. (2010) Antioxidant activity of $100 \%$ and $80 \%$ methanol extracts from barley seeds (Hordeumvulgare L): Stabilition of sunflower oil. Grasas Y Aceites, 61, 237-243. doi:10.3989/gya.087409

[46] Frankel E.N. (1998) Lipid oxidation. The Oily Press Dundee, Scotland. Ltd., Bridgewater.

[47] Kamal-Eldin, A. and Appelqvist, L.A. (1996) The chemistry and antioxidant properties of tocopherols and tocotrienols. Lipids, 31, 671-701. doi:10.1007/BF02522884 